Canadian

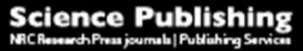

Botany

Botanique

\title{
Interface between fungi and green algae in lichen associations
}

\begin{tabular}{|r|l|}
\hline Journal: & Botany \\
\hline Manuscript ID & cjb-2017-0037.R2 \\
\hline Manuscript Type: & Review \\
\hline Date Submitted by the Author: & 07-May-2017 \\
\hline $\begin{array}{r}\text { Complete List of Authors: } \\
\text { Is the invited manuscript for } \\
\text { consideration in a Special } \\
\text { Issue? : }\end{array}$ & $\begin{array}{l}\text { Piercey-Normore, Michele; Memorial University of NL, Science and the } \\
\text { Athukorala, Sarangi; University of Peradeniya, Department of Botany }\end{array}$ \\
\hline Keyword: & interaction, lichen fungi, resynthesis, symbiont communication \\
\hline & \\
\hline
\end{tabular}

\section{SCHOLARONE ${ }^{\text {M }}$ \\ Manuscripts}


Mini review - Botany

\section{Interface between fungi and green algae in lichen associations}

Michele D. Piercey-Normore ${ }^{1}$ and Sarangi N. P. Athukorala ${ }^{2}$

${ }^{1}$ School of Science and the Environment, Memorial University of NL (Grenfell campus), Corner Brook, NL, Canada, A2K 5G4, mpiercey-normore@grenfell.mun.ca

${ }^{2}$ Department of Botany, Faculty of Science, University of Peradeniya, Peradeniya, Sri Lanka, 20400, sarangi a@yahoo.com

Corresponding author:

M. D. Piercey-Normore, School of Science and the Environment, Memorial University of NL (Grenfell campus), Corner Brook, NL, Canada, A2K 5G4, email: mpierceynormore@grenfell.mun.ca, phone: (709) 637-7166. 


\begin{abstract}
It is widely recognized that the lichen is the product of a fungus and a photosynthetic partner (green alga or cyanobacterium) but its acceptance was slow to develop throughout history. The development of powerful microscopic and other lab techniques enabled better understanding of the interface between symbionts beginning with the contentious concept of the dual nature of the lichen thallus. Even with accelerating progress in understanding the interface between symbionts, much more work is needed to reach a level of knowledge consistent with that of other fungal interactions. This review describes the interface between algal and fungal symbionts in lichens, including the appearance of interacting symbionts, our current understanding of communication between symbionts, and emerging new concepts in light of the challenges and debates that have provided lichenology with an enriched history. Communication between symbionts occurs before physical contact, which has been studied by microscopy, movement of molecules between symbionts, and gene expression studies. New discoveries include the interaction with more than one alga in a lichen thallus as well as other unrelated fungi and bacteria typically found on or within the thallus. This mini review briefly describes our current state of knowledge and highlights new directions for further study.
\end{abstract}

Keywords: interaction, lichen fungi, resynthesis, symbiont communication. 


\section{Introduction}

The history of lichenology has been replete with opposing viewpoints over the nature of the symbiosis. The dual nature of the lichen thallus - fungal and algal (or cyanobacterial) symbionts - began to emerge in the early 1800's and became established in the literature through Schwendener's work in the latter half of the 1800's (Honegger 2000) as microscopy improved enough to provide visual evidence of the presence of different symbionts. The acceptance of the dual hypothesis of lichens swung back and forth, and eventually became accepted by contemporary biologists. The difficulty was whether to accept the two taxonomically and evolutionary distantly related symbionts, which come together to produce a thallus that in most cases looks different from either of the symbionts alone, or to recognize the lichen as a single entity with its own taxonomic status. This resulted in the dual hypothesis remaining uncertain for almost a century until the middle of the 1900's and later.

When the use of DNA and more powerful microscopic techniques began to address research questions in the 1990's, it necessitated the separate consideration of the thallus genomes in order to carry out many DNA based studies. However, in some circles, a controversy over lichen taxonomy still continues especially where lichen taxonomy or physiology requires recognition of the morphology of the entire thallus or one fungus forms two morphologically different thalli (Goward 2010; Magain and Sérusiaux 2015). Scanning and transmission electron microscopy provided detailed images of the interface between the two symbionts (Honegger 1984, 1986a, 1986b, 1990, 1991a, 1991b, 1992, 1993 and references therein), which entrenched the dual nature of the lichen thallus. The use of both DNA-based and more powerful microscopic techniques opened doors to allow for further hypothesis-driven research directions. 
Additional challenges in lichenology have resulted in the continued slow pace of experimentation but some of the more significant issues result from laboratory manipulation of the symbionts. One challenge, to determine whether the fungus in culture is the same fungus that forms the thallus of the lichen or if it is a non-symbiotic fungus that was present on the thallus surface, has been addressed by standard comparison of the ITS rDNA genes of both the cultured and natural lichen thallus. A second challenge, even though the ontogenetic steps have been similar in the species studied thus far (Stocker-Wörgötter 2001), was that the 17,500-20,000 known species of lichens (Kirk et al. 2008) will likely exhibit variation in the details of the interface between symbionts. A third set of challenges has been in the culturing of the symbionts; the growth of faster growing fungal contaminants, instead of the slow-growing lichen fungal cultures, the maintenance of the fungal culture for extended time periods (Ahmadjian 1989), and the need for the presence of a compatible symbiotic partner to trigger a fungal response (Meeßen et al. 2013).

Increased knowledge about the interface between the fungus and alga, including the ontogeny development, has become more germane to the understanding of cellular communication in lichen symbionts. Additional research has already lead to discovery of other organisms involved in the symbiosis, questions on their function and economic benefit, and novel enzymes and other products of the fungi, algae and bacteria involved (Bates et al. 2011; Cernava et al. 2015). An understanding of the genes involved at the interface is just beginning and if the genes are analogous to those of antagonistic interactions in plant pathogenic interactions, there may be benefits to be gained in terms of plant pathology and genetic mechanisms. 
Advances in culturing methods and laboratory manipulation have increased the pace of lichenological research and have introduced other unforeseen and sometimes controversial findings. It is an exciting time for lichenology with fuel for many ongoing philosophical and passionate debates. The goal of this mini review is to briefly review what is known about the interface between algal and fungal symbionts in lichens including the morphology, communication between symbionts, and emerging new concepts in light of the inherent challenges and debates.

\section{The fungal-algal interface: Culturing and resynthesis}

\section{Isolation and culturing of symbionts}

Isolation and culturing of lichen symbionts involves physical separation from the intact thallus and growth of the fungus and the alga on a defined growth medium under controlled laboratory conditions. Methods were developed over time to isolate each of the symbionts but they were often time consuming and relied on a large number of isolations to obtain just a few uncontaminated cultures. The micropipette technique produced individual algal cells from a lichen homogenate by selecting algal cells for culture (Ahmadjian 1973). The use of macerated thallus fragments and two sieve sizes (Yamamoto et al. 1987; Yoshimura et al. 1987) further allowed the isolation of both symbionts using different media compositions. A spore rain method (Ahmadjian 1966, 1973) improved the ability to obtain the fungal partner in culture by utilizing the natural release of ascospores from asci and their subsequent growth in culture. Homogenization of the lichen thallus, followed by separation of the alga from the fungus with gradient centrifugation on cesium chloride and potassium iodide (Ascaso 1980) or on Percoll® gradients (Gasulla et al. 2010), and/or filtering (Weissman et al. 2005) have also been used for 
rapid isolation of algal or cyanobacterial symbionts (Elshobary et al. 2016). As these isolation methods developed, the challenge to find optimal growing conditions became a focus, since conditions that have been optimized for symbionts from one lichen species may not be suitable for other species (Stocker-Wörgötter 1991; Yoshimura et al. 1993; Crittenden et al. 1995; Sangvichien et al. 2011; McDonald et al. 2013). Suitable growing conditions are currently unknown for the symbionts of some of the physiologically obligate species (McDonald et al. 2013). In addition, endolichenic fungi and external fungal and bacterial contaminants are common (Arnold et al. 2009; U'Ren et al. 2010), making isolation and identification of the lichen fungus difficult to confirm. With improvements in culturing techniques having facilitated the use of lichen symbionts in experimental studies (Oliver et al. 1989; Jahns 1993; Crittenden et al. 1995; Stocker-Wörgötter 2001, 2002; Sangvichien et al. 2011; McDonald et al. 2013; Athukorala et al. 2014a, 2014b; Athukorala et al. 2015) and the resynthesis of the lichen thalli under in vitro conditions (Ahmadjian 1993; Athukorala et al. 2014a), the momentum in experimentation is increasing.

\section{Resynthesis and Koch's postulates}

Koch's postulates have been used as a reference to identify the causal disease agent for plant and animal diseases for over a century (e.g. Falkow 2004; Fernando et al. 2005). Robert Koch postulated that a parasite is the causal agent of a disease if three conditions (paraphrased here) are met: the parasite is present in every case of the disease; the parasite occurs in no other disease; and after isolation and grown in culture, it can induce the disease again when inoculated with the host (Evans 1976). Revised postulates have been proposed since the original postulates were published in 1840 to account for viral diseases (Evans 1976; Fouchier et al. 2003) and for 
obligate parasites using reproducible sequence-based evidence of the causal agent (Falkow 1988; Fredericks and Relman 1996).

Resynthesis experiments have faced problems with species confirmation since the cultured lichen-fungus has a different morphology than the natural lichen. Additionally, the taxonomic range of symbiont combinations forming the interaction either at early reassociation stages or complete resynthesis of the lichen thallus is unknown. While Koch's postulates have been effectively applied to the lichen association since Ahmadjian's work (1993 and references therein), the use of DNA sequence comparisons (Stocker-Wörgötter 2001; Athukorala et al. 2014a) and measurable morphological features such as the algal cell diameter, number of hyphal branches, and internode length, has been applied only recently (Trembley et al. 2002; Joneson and Lutzoni 2009; Athukorala et al. 2014a). Recognition of Koch's postulates for lichen symbiont resynthesis allows for experimental validity and measurable responses with other nonsymbiont algal interactions. The separation of the individual symbionts into pure cultures, and the reintroduction of the symbionts in culture to produce the original controlled parasitic interaction, or complete thallus resynthesis in culture has been elusive in lichenology (Grube et al. 2014). Challenges persist in the resynthesis of lichen symbionts and further experimentation with the symbionts (Grube et al. 2014).

Resynthesis studies have allowed researchers to observe the initial stages of the lichenization process, but in some cases these initial stages are terminated before a lichen thallus is produced (Athukorala et al. 2014a). This relichenized thallus would provide the morphological characteristics needed to identify the lichen taxon. The compatibility between co-cultured symbionts is generally used as evidence for the natural in vivo symbionts (Webber and Webber 1970; Jacobs and Ahmadjian 1971; Ahmadjian et al. 1978; Ahmadjian and Jacobs 1981; Ott 
1987a; Ott et al. 1995; Schaper and Ott 2003; Meeßen et al. 2013), or the "causal agents" of the controlled lichen parasitism. Any other result such as overgrowth of symbionts without the initial five stages of a lichen interaction (see next paragraph) or death of one of the symbionts (Ahmadjian and Jacobs 1981) may suggest no interaction or a virulent parasitism. Algal species, other than the in vivo partner, have been found to interact with Cladonia rangiferina (L.) F. H. Wigg. (Athukorala et al. 2014a). Similar results were reported for Protoparmeliopsis muralis (Schreber) M. Choisy as the non-natural alga, Asterochloris, produced interactions in culture (Guzow-Krzeminska and Stocker-Wörgötter 2013) and for Fulgensia bracteata (syn.

Gyalolechia bracteata (Hoffm.) A. Massal.) with presumably non-compatible algal partners (Schaper and Ott 2003). These abilities to form partial interactions may allow for the fungus to survive temporarily in nature until it interacts with the compatible algal partner or for the colonization of non-optimal or marginal habitats by the lichen (Ott 1987b; Galun and Garty 1988; Honegger 1990, 1993; Beck et al. 1998; Honegger 2012).

Studies in the in vitro and in situ resynthesis between lichen symbionts have provided a better understanding of the cellular changes during the interaction (Ahmadjian et al. 1980; Bubrick et al. 1985; Ott 1987a; Galun and Garty 1988; Stocker-Wörgötter and Türk 1991; Jahns 1993; Kon et al. 1993; Stocker-Wörgötter 1995; Schaper and Ott 2003; Joneson and Lutzoni 2009; Athukorala et al. 2014a). Cell characteristics of the co-inoculated symbionts in species of Xanthoria and Cladonia have been described for five stages of the interaction: a "pre-contact" stage shows symbionts which are not in physical contact but are close enough to share extracellular excretions; a "contact" stage shows the alga and fungus beginning to make physical contact by appressorial-like structures; a "growth together" stage shows the coordinated growth of the symbionts forming a cellular mass; a "transitional pre-thallus" stage shows the formation 
of an undifferentiated thallus-like structure; and finally the production of a stratified thallus (Ahmadjian et al. 1978; Galun 1988; Armaleo 1991). The last two stages often require additional culture conditions and have been less commonly investigated, but Marton and Galun (1976) provided evidence for the complete thallus formation in Heppia echinulata Marton and Galun. Other studies have also been successful in achieving complete thallus development (e.g., Thomas 1939; Ahmadjian and Jacobs 1983).

Resynthesis studies have also shown that the nature of resynthesis stages and the time taken to reach each stage may differ among lichen species and may be specific to laboratory conditions and growth media. For example, the contact stage has been shown to occur at 8 days post co-inoculation (PCI) with Cladonia rangiferina (Athukorala et al. 2014a), 12 days PCI in Baeomyces rufus (Hudson) Rebent. (Trembley et al. 2002), and 21 days PCI with C. grayi G. Merr. Ex Sandst. (Joneson and Lutzoni 2009). Haustorial frequencies also varied (Durrell 1967; Ahmadjian et al. 1978; Ahmadjian and Jacobs 1981; Athukorala 2014a). Some species-specific variation is expected and the inconsistency between studies may be the result of different conditions for preparation and growth of the cultures.

As the number of resynthesis studies are increasing, we are learning that the five stages need optimization and definition for different laboratories for each species, which may further influence the timing and perhaps cellular triggers for interactions among symbiont species. Depending on the specific experimental conditions, the cellular triggers may result in antagonistic interactions. The growth rates of algal partner and fungal mycelium present in the culture during the co-inoculation may have influenced the degree of parasitism for the fungus on Chlorella as was hypothesized with Cladonia rangiferina (Athukorala et al. 2014a) or the biomass ratio and contact time of both symbionts may affect recognition and nutrient transfer 
(Wang et al. 2014). While similarity exists in the types of structures and stages of the interactions, the variability in degree of antagonism with the natural or non-natural algal partner may vary to reflect unobserved interactions in nature that allow for success of the lichen.

\section{The fungal-algal interface: Communication between symbionts}

After the initial recognition between symbionts, further communication occurs through the formation of specialized physical connections between fungal hyphae and algal cells, some forming well developed haustoria and others forming a simple contact point at the interface (Honegger 1986a). The types of haustoria are reviewed in Honegger (1984, 1986a, 1990, 1991a, $1991 b, 1992,1993)$. In most lichens, the fungal hyphae do not pierce the cell wall of the alga where they form peg-like structures called appressoria. Appressoria may then develop into intraparietal haustoria (Honegger 1985, 1986a, 1991a) where they may dissolve the inner algal wall layer (Pérez-Ortega et al. 2010). These haustoria are found in lichens with algae belonging to the genera Coccomyxa, Elliptochloris (Brunner and Honegger 1985; Honegger 1991b), Myrmecia and Dictyochloropsis (Honegger 1990, 1991b, 1992). Some of the more primitive crustose lichens have transparietal (intracellular) haustoria, which pierce the cell wall and are in contact with the plasma membranes of the algal cells (Honegger 1984, 1986b, 1993). The surface of the interacting hypha and the algal cell becomes coated in a layer of protein and fatty acids, which has been described as mucilage (Honegger 1986b). The mucilage also contains crystals of secondary metabolites, which have been hypothesized to play a role in pattern formation of the thallus (Honegger $1986 b$ and references therein). Hypotheses on the communication between fungal hyphae and algal cells in lichen associations have been presented by Richardson (1985), Legaz (1985) and Vicente (1985), which provide insights for further research on this topic. 
The first and second stages of the interaction between symbionts have been examined with respect to physiological processes (Richardson et al. 1968) and enzyme production by symbionts (Legaz and Vicente 1982). The understanding of processes has been improved, including the role of lichen lectins and other molecules in the recognition of compatible algal partners (Molina et al. 1993; Athukorala et al. 2015), gene expression in both partners during the symbiont interaction (Joneson et al. 2011; Athukorala et al. 2015; Hametner and StockerWörgötter 2015), and mechanisms for drought tolerance in lichens (Honegger 1996) under controlled conditions. Recognition between cells of the symbionts is the first step in the association, which was examined by Joneson and Lutzoni (2009). During this first stage, random growth brought the symbionts together (Ahmadjian 1959; Clayden 1998; Joneson and Lutzoni 2009), and others found that hyphal growth made contact with a non-compatible alga (Schaper and Ott 2003; Guzow-Krzeminska and Stocker-Wörgötter 2013; Athukorala et al. 2014a), which may have supported the observation of random growth.

During the interaction between symbionts, mucilage production (Ahmadjian and Jacobs 1983; Garty and Delarea 1987; Ott 1987a; Schaper and Ott 2003; Meeßen and Ott 2013) was suggested to be important for specificity in symbiont recognition, successful lichenization and early lichenization (Meeßen and Ott 2013). Mucilage formation has been observed by Trembley et al. (2002) during Baeomyces rufus resynthesis $24 \mathrm{~h}$ post co-inoculation (PCI) and in Cladonia rangiferina by Athukorala et al. (2014a). Ott (1987a) indicates that extensive mucilage production is a vital characteristic during the resynthesis of Xanthoria parietina and Fulgensia bracteata (Schaper and Ott 2003). Protein binding to the symbiotic algae was recognized in early studies (Bubrick and Galun 1980; Bubrick et al. 1981) where it was hypothesized to play a role in recognition between the symbionts. Other molecules produced during the interaction include 
argenase and urease (Legaz et al. 2004) and lectin receptors (Molina et al. 1993; Molina and Vicente 1995) important for prevention of algal cell death during the interaction. The urease, which is bound to compatible algal cell walls, acts s a receptor for the fungal arginase-like proteins and prevents them from entering the algal cell (Millanes et al. 2004). When the arginases enter the algal cells in incompatible algae, they initiate the production of putrescine, which causes the algal cell components to break down and eventually result in the death of the algal cell. The lectin, concanavalin A, was reported to bind to a ligand in the cell walls of some lichen algae, which was thought to be different from the previously described urease receptor of algae (Fontaniella et al. 2004).

\section{Gene expression during symbiont interaction}

During the last decade, advances in the application of molecular techniques to lichenology have resulted in gene expression studies on the interaction. Initial studies examined DNA from both symbiont genomes extracted from the thallus, but further development of co-inoculation techniques in culture allowed the ability to perform gene expression studies during symbiont interaction under laboratory conditions using quantitative methods such as quantitative Real Time PCR. However, few studies using quantitative techniques have been conducted and the progress is slow mainly due to problems encountered in culturing, lack of GenBank information, and genetic resources available on lichen symbionts. These few studies suggest that the symbiont interaction shares events similar to those of parasitic or mycorrhizal interactions, where communication and the initial recognition between compatible partners is necessary for successful interactions (Joneson et al. 2011; Athukorala et al. 2015). 
As established in plant-pathogenic interactions, the nature of the gene-to-gene interaction determines the nature of the interaction between the partners, whereby successful recognition resulting from gene-for-gene interaction will turn on defense mechanisms of the plant or alga, which limits the fungal invasion. The first study to compare the gene expression profiles of symbionts in both symbiotic and aposymbiotic (cultured alone) states, revealed that many algal and fungal genes were suppressed in the symbiotic state (Trembley et al. 2002). Two later studies provided additional knowledge of the genetic background of the role of recognition and defense responses during successful lichen symbiosis (Joneson et al. 2011; Miao et al. 2012; Athukorala et al. 2015). In addition, changes in gene expression involved in fungal and algal metabolism have been observed (Joneson et al. 2011; Wang et al. 2014), suggesting that a change in the expression of an array of genes responsible for a variety of functions in the compatible partners is needed for lichenization. Although the initiation of gene expression studies facilitated the development of hypotheses behind the lichen interaction, there is much yet to be discovered. One of the future directions in lichenology is to better understand the genetic mechanisms underlying this intimate relationship similar to that of a mycorrhizal association where phylogenomics generated hypotheses around the regulation of jasmonate signaling in poplar (Martin et al. 2016).

\section{Emerging concepts}

\section{Number of symbiotic partners}

Some lichen fungal species have been shown to associate with more than one algal species in nature (Kroken and Taylor 2001; Beck et al. 2002; Yahr et al. 2004; Blaha et al. 2005; PierceyNormore 2006; Yahr et al. 2006; and references therein). In one example, three species of 
Cladonia associated with two different Asterochloris haplotypes in different geographic regions (Piercey-Normore 2004) suggesting that both species recognition and habitat may play roles in symbiont combinations. Single thalli of Evernia mesomorpha Nyl. may have associated with up to five algal species or genotypes in the genus Trebouxia simultaneously (Piercey-Normore 2006). It was hypothesized that the algae may have allowed adaptation to environmental conditions at different levels of the canopy. Association with multiple algae has also been shown by del Campo et al. (2013) in Ramalina farinacea (L.) Ach., where physiological correlations between the type of photobiont and high temperatures were made. Additionally, Muggia et al. (2013) showed that algae from two different genera formed interactions with Protoparmeliopsis muralis. This low selectivity of the algal partner has been used to explain ecological tolerance and evolutionary divergence of lichen species (Muggia et al. 2014). Together, these lines of evidence suggest an ability to adapt to a wide variety of conditions, which may promote diversification into new niches as algal tolerance is shifted across host taxa.

While these studies were documenting low selectivity of algae associated with lichen fungi, other studies were discovering a diversity of taxa that were found within the lichen thallus and raised questions regarding the level of involvement of other organisms in lichen thallus development and adaptation to new niches. Other non-lichenizing fungi (Harutyunyan et al. 2008; Werth et al. 2013; Muggia et al. 2016) and bacteria (Cardinale et al. 2008; Grube and Berg 2009) were reported from cultures of lichen thalli. Some studies have suggested that the bacteria contribute to metabolic activity of the lichen symbionts (Liba et al. 2006; Grube et al. 2009, 2014). Other studies provided evidence to support a co-dispersal of a bacterial community with vegetative propagules of Lobaria pulmonaria (L.) Hoffm. (Aschenbrenner et al. 2014) and possible roles of the Rhizobiales in the thallus of $L$. pulmonaria including auxin and vitamin 
production, nitrogen fixation and stress protection (Erlacher et al. 2015). Muggia et al. (2013) showed the presence of algae on the thallus surface of Protoparmeliopsis muralis, which were hypothesized to be able to form lichens with unrelated lichen fungi. Basidiomycete yeasts in the thallus cortex have also been hypothesized to play an important role in thallus morphology (Spribille et al. 2016). These studies continue to raise questions about the "need" or tolerance of the lichen symbionts for these associated communities, the source of the communities, and the specificity or variability of these associated communities. While the presence of these associated communities has clearly been shown in multiple studies with molecular, culture, and ultrastructure evidence, the level of participation in the physiology and evolutionary adaptations is still unknown and is controversial among lichenologists.

\section{Black fungi and algal interactions}

Bare rock surfaces provide a hostile environment especially when the rock surface is in a harsh climate such as the Antarctic or deserts. The rock surface provides an oligotrophic habitat inundated with high levels of ultraviolet light and extremes of temperature and moisture availability making it difficult for many organisms to survive in those conditions. Black fungi or microcolonial fungi in the Dothidiomycetes and Chaetothyriomycetidae are highly desiccation tolerant, melanized, and adapted to oligotrophic conditions (Staley et al. 1982), which has also been hypothesized for lichen-forming fungi (Gostincar et al. 2012). Interactions between black fungi and common lichen photobionts have been studied in culture (Gorbushina et al. 2005; Brunauer et al. 2007) showing that interactions occur which allow the fungus and alga to continue to grow in a balanced parasitic interaction (Turian 1977), linking these black fungi with lichen-forming fungi. Gorbushina et al. (2005) showed similar morphological changes to those of 
compatible interactions in lichen symbionts, including characteristics where the branching of fungal hyphae was more common in the vicinity of algal cells, algal cell size was not changed, cell contacts between algal and fungal cells occurred, and mucilage was produced. These "borderline lichens" (Kohlmeyer et al. 2004) were hypothesized to persist as an adaptation to the inhospitable rock-dwelling habitat. Phylogenetic analyses have also shown close relationships between black fungi and lichen-forming fungi (Muggia et al. 2013) and it has been hypothesized that algal interactions with black fungi represent the primitive stages of lichenization (Gostincar et al. 2012). The rare observation of antibiosis in rock-inhabiting or other oligotrophic habitats with high metabolic costs (Friedman and Ocampo-Friedman 1984) would ensure survival and account for the high specificity evolved within some of the lichen forming fungal clades (Opanowicz and Grube 2004; Piercey-Normore 2006, 2009; Doering and Piercey-Normore 2009; Fernández-Mendoza et al. 2011; Leavitt et al. 2015). Borderline lichens also persist in other morphological forms such as having a loose aggregation of hyphae among algal cells in which the algal cells may be free-living (Hawksworth 2004) or endosymbiotic cyanobacteria as in Geosiphon pyriforme (Kütz.) F. Wettst., which are thought to be related to mycorrhizae (Gehrig et al. 1996).

\section{Concluding comments}

Studies on the cellular interactions in lichen associations from various perspectives have provided a better understanding of lichen associations but the topic is still in its infancy. Future research on cellular interactions may lead toward a more complete physiological understanding of the cell to cell communication prior to and during the initial stages of the interaction using a combination of cell biology and gene regulation methods. One promising new method is laser 
microdissection, which allows better understanding of the physical location of active genes and biological functions within a lichen thallus, and has been used with plants (e.g., Chan et al. 2016). The regulation of biosynthetic gene clusters triggered by specific growing conditions, may allow for improved biotechnology advances, which is a current focus of research in nonlichenized fungi (Lim et al. 2012). Similar strategies of cellular communication with fungi that are parasitic on plants and other organisms may provide support for the controlled parasitism with allowance for ecological, reproductive, and physiological variability.

The range and specificity of symbiotic partners inclusive of eukaryotic and prokaryotic partners involved in interactions is still unknown. Variability and tolerance to additional symbiotic partners is a necessary requirement for adaptation to environmental change. Adaptation can also be studied in the laboratory by better understanding culture conditions for lichen symbionts allowing for more controlled experiments and precise manipulation of variables. A better understanding of the role of organisms that occur on and within the lichen thallus is a direction of future study (Cernava et al. 2015; Muggia et al. 2016). Improved knowledge of the range and responses of these symbionts may shed light on the lichen symbiont communication process as well as the evolutionary history of the lichen association with black fungi and algal interactions.

The ability to sequence genomes has also allowed for a potential acceleration of knowledge around the issues in lichenology leading to comparative studies in genomic and transcriptomic experiments (Juntilla et al. 2013; Grube et al. 2014; Wang et al. 2014). These studies address questions around the genetic mechanisms involved in the interaction between symbionts and may reveal cascades of biosynthetic genes and their products (e.g., Ren et al. 2008). A better understanding of the genetic machinery in the symbiont interaction may draw 
parallels with pathogenic fungi and lead to modification of our approach to disease management in agriculture, forestry, and other disciplines.

\section{Acknowledgements}

The authors thank Y. Dalpé and S. Berch for organizing the mycology symposium on "Fungi at the Edge" at the CBA-ABC meeting in Victoria (May 2016), which made this special issue possible. Recognition of the Ph.D. thesis of SNPA is acknowledged, which provided context for this review.

\section{References}

Ahmadjian, V. 1959. A contribution toward lichen synthesis. Mycologia, 51: 56-60.

Ahmadjian, V. 1966. Artificial reestablishment of the lichen Cladonia cristatella. Science, 151: 199-201.

Ahmadjian, V. 1973. Methods of isolating and culturing lichen symbionts and thalli. In The lichens. Edited by V. Ahmadjian, and M.E. Hale, Academic, New York. pp. 653-665. Ahmadjian, V. 1989. Studies on the isolation and synthesis of bionts of the cyanolichen Peltigera canina (Peltigeraceae). Plant Syst. Evol. 165(1): 29-38.

Ahmadjian, V. 1993. The Lichen Symbiosis. New York: John Wiley and Sons.

Ahmadjian, V., and Jacobs, J.B. 1981. Relationship between fungus and alga in the lichen Cladonia cristatella Tuck. Nature, 289: 169-172.

Ahmadjian, V., and Jacobs, J.B. 1983. Algal-fungal relationships in lichens: Recognition, synthesis and development. In Algal Symbiosis. Edited by L. J. Goff. Cambridge, Cambridge University Press, Cambridge. pp. 147-172. 
Ahmadjian, V., Jacobs, J.B., and Russell, L.A. 1978. Scanning electron microscope study of early lichen synthesis. Science, 200: 1062-1064.

Ahmadjian, V., Russel, L.A., and Hildreth, K.C. 1980. Artificial reestablishment of lichens. I. Morphological interactions between the phycobionts of different lichens and the mycobionts Cladonia cristatella and Lecanora chrysoleuca. Mycologia, 72: 73-89.

Armaleo, D. 1991. Experimental microbiology of lichens: mycelia fragmentation, a novel growth chamber, and the origins of thallus differentiation. Symbiosis, 11: 163-178.

Arnold, A.E., Miadlikowska, J., Higgins, K.L., Sarvate, S.D., Gugger, P., Way, A., Hofstetter, V., Kauff, F., and Lutzoni, F. 2009. A phylogenetic estimation of trophic transition networks for ascomycetous fungi: are lichens cradles of symbiotrophic fungal diversification? Syst. Biol. 58: 283-297.

Ascaso, C. 1980. A rapid method for the quantitative isolation of green algae from lichens. Ann. Bot. 45: 483.

Aschenbrenner, I.A., Cardinale, M., Berg, G., and Grube, M. 2014. Microbial cargo: do bacteria on symbiotic propagules reinforce the microbiome of lichens? Environ. Microbiol. 16(12): 3743-3752.

Athukorala, S.N.P., Huebner, E., and Piercey-Normore, M.D. 2014a. Identification and comparison of the three early stages of resynthesis for the lichen Cladonia rangiferina. Can. J. Microbiol. 60: 41-52.

Athukorala, S.N.P., and Piercey-Normore, M.D. 2014b. Effect of temperature and $\mathrm{pH}$ on the resynthesis of compatible partners of the lichen, C. rangiferina. Symbiosis, 64: 87-93. 
Athukorala, S.N.P., and Piercey-Normore, M.D. 2015. Recognition and defense-related gene expression at three resynthesis stages in lichen symbionts. Can. J. Microbiol. 61: 1-12. doi:10.1139/cjm-2014-0470.

Bates, S.T., Cropsey, G.W.G., Caporaso, J.G., Knight, R., and Fierer, N. 2011. Bacterial communities associated with the lichen symbiosis. Appl. Environ. Microbiol. 77: 13091314.

Beck, A., Friedl, T., and Rambold, G. 1998. Selectivity of photobiont choice in a defined lichen community: inferences from cultural and molecular studies. New Phytologist, 139(4): 709-720.

Beck, A., Kasalicky, T., and Rambold, G. 2002. Myco-photobiontal selection in a Mediterranean cryptogam community with Fulgensia fulgida. New Phytologist, 153: 317-326.

Blaha, J., Baloch, E., and Grube, M. 2006. High photobiont diversity associated with the euryoecious lichen-forming ascomycete Lecanora rupicola (Lecanoraceae, Ascomycota). Biol. J. Linn. Soc. 88: 283-293. doi:10.1111/j.1095-8312.2006.00640.x.

Brunauer, G., Blaha, J., Hager, A., Türk, R., Stocker-Wörgötter, E., and Grube, M. 2007. An isolated lichenicolous fungus forms lichenoid structures when co-cultured with various coccoid algae. Symbiosis, 44: 127-36.

Brunner, U., and Honegger, R. 1985. Chemical and ultrastructural studies on the distribution of sporopollenin-like biopolymers in 6 genera of lichen phycobionts. Can. J. Bot. 63: 22212230.

Bubrick, P., Frensdorff, A., and Galun, M. 1985. Selectivity in the lichen symbiosis. In Lichen Physiology and Cell Biology. Edited by D.H. Brown. Plenum, New York. pp. 319-334. Bubrick, P., and Galun, M. 1980. Proteins from the lichen Xanthoria parietina which bind to 
phycobiont cell walls. Correlation between binding patterns and cell wall cytochemistry. Protoplasma, 104: 167-173.

Bubrick, P., Galun, M., and Frensdorff, A. 1981. Proteins from the lichen Xanthoria parietina which bind to phycobiont cell walls. Localization in the intact lichen and cultured mycobiont. Protoplasma, 105: 207-211.

Del Campo, E. M., Catala, S., Gimeno, J., del Hoyo, A., Martinez-Alberola, F., Casano, L. M., Grube, M., and Barreno, E. 2013. The genetic structure of the cosmopolitan three-partner lichen Ramalina farinacea evidences the concerted diversification of symbionts. FEMS Microbiol. Ecol. 83: 310-323.

Cardinale, J., de Castro, Jr., Müller, V.H., Berg, G., and Grube, M. 2008. In situ analysis of the bacterial community associated with the reindeer lichen Cladonia arbuscula reveals predominance of Alphaproteobacteria. FEMS Microbiol. Ecol. 66(1): 63-71.

Cernava, T., Müller, H., Aschenbrenner, I.A., Grube, M., and Berg, G. 2015. Analyzing the antagonistic potential of the lichen microbiome against pathogens by bridging metagenomic with culture studies. Front. Microbiol. 6: 620.

Chan, A.C., Khan, D., Girard, I.J., Millar, J.L., Becker, M.G., and Belmonte, M.F. 2016. Tissue specific laser microdissection of the Brassica napus funiculus improves gene discovery and spatial identification of biological processes. J. Exp. Bot. 67: 3561-3571 doi:10.1093/jxb/erw179.

Clayden, S.T. 1998. Thallus initiation and development in the lichen Rhizocarpon lecanorinum. New Phytologist, 139: 685-695 
Crittenden, P.D., David, J.C., Hawksworth, D.L., and Campbell, F.S. 1995. Attempted isolation and success in the culturing of a broad spectrum of lichen-forming and lichenicolous fungi. New Phytologist, 130: 267-297.

Doering, M., and Piercey-Normore, M.D. 2009. Genetically divergent algae shape an epiphytic lichen community on Jack Pine in Manitoba. Lichenologist, 41: 1-12.

Durrell, L.W. 1967. An electron microscope study of algal hyphal contact in lichens. Mycopathologia et Mycologia Applicata, 31: 273-286.

Elshobary, M.E., Osman, M.E., Abo-Shady, A.M., Komatsu, E., Perreault, H., Sorensen, J. and Piercey-Normore, M.D. 2016. Effect of algal carbohydrates on polyketide synthesis of the lichen-forming fungus, Cladonia rangiferina. Mycologia, 108: 646-656. doi:10.3852/15-263.

Erlacher, A., Cernava, T., Cardinale, M., Soh, J., Sensen, C.W., Grube, M., and Berg, G. 2015. Rhizobiales as functional and endosymbiontic members in the lichen symbiosis of Lobaria pulmonaria L. Front. Microbiol. 6: 1-9.

Evans, A.S. 1976. Causation and Disease: The Henle-Koch postulates revisited. The Yale Journal of Biology and Medicine, 49: 175-195.

Falkow, S. 1988. Molecular Koch's postulates applied to microbial pathogenicity. Reviews of Infectious Diseases, 10 (Suppl 2): S274-6. doi:10.1093/cid/10.Supplement_2.S274.

Falkow, S. 2004. Molecular Koch's postulates applied to bacterial pathogenicity - a personal recollection 15 years later. Nature Rev. Microbiol. 2: 67-72. doi:10.1038/nrmicro799.

Fernández-Mendoza, F., Domaschke, S., Garciá, M.A., Jordan, P., Martiń, M.P., and Printzen, C. 2011. Population structure of mycobionts and photobionts of the widespread lichen Cetraria aculeata. Mol. Ecol. 20: 1208-1232. 
Fernando, W.G.D., Zhang, J.X., Chen, C.Q., Remphrey, W.R., Schurko, A., and Klassen, G.R. 2005. Molecular and morphological characteristics of Apiosporina morbosa, the causal agent of black knot in Prunus spp. Can. J. Plant Pathol. 27: 364-375.

Fontaniella, B., Millanes, A-M., Vicente, C., Legaz, M-E. 2004. Concanavalin A binds to a mannose-containing ligand in the cell wall of some lichen phycobionts. Plant Physiol. Biochem. 42: 773-779.

Fouchier, R.A.M., Kuiken, T., Schutten, M., van Amerongen, G., van Doornum, G.J.J., van den Hoogen, B.G., Peiris, M., Lim, W., Stöhr, K., and Osterhaus, A.D.M.E. 2003. Koch’s postulates fulfilled for SARS virus. Nature, 423: 240 .

Fredericks, D.N., and Relman, D.A. 1996. Sequence-based identification of microbial pathogens: a reconsideration of Koch's postulates. Clin. Microbiol. Rev. 9: 18-33.

Friedmann, E. I., and Ocampo-Friedmann, R. 1984. Endolithic microorganisms in extremely dry environments: analysis of a lithobiontic microbial habitat. In Current Perspectives in Microbial Ecology. Edited by M.J. Klug and C.A. Reddy, American Society for Microbiology, Washington, DC. pp. 177-185.

Galun, M. 1988. Lichenization. In CRC Handbook of Lichenology, II. Edited by M. Galun, CRC Press, Boca Raton. pp. 153-169.

Galun, M., and Garty, J. 1988. Soredia formation of compatible and incompatible lichen symbionts. In Cell to Cell Signals in Plant, Animals and Microbial Symbiosis H17. Edited by S. Scannerini, P. Bonfante-Fasolo, V. Gianinazzi-Pearson. Springer-Verlag, Berlin. pp. 207-217.

Garty, J., and Delarea, J. 1987. Some initial stages in the formation of epilithic crustose lichens in nature: a SEM study. Symbiosis, 3: 49-56. 
Gasulla, F., Guéra, A., and Barreno, E. 2010. A simple and rapid method for isolating lichen photobionts. Symbiosis, 51(2): 175-179.

Gehrig, H., Schüssler, A., and Kluge, M. 1996. Geosiphon pyriforme, a fungus forming endocytobiosis with Nostoc (cyanobacteria), is an ancestral member of the Glomales: evidence by SSU rRNA analysis. J. Mol. Evol. 43: 71-81.

Gorbushina, A.A., Beck, A., and Schulte, A. 2005. Microcolonial rock inhabiting fungi and lichen photobionts: evidence for mutualistic interactions. Mycological Research, 109 (11): $1288-1296$.

Gostincar, C., Muggia, L., and Grube, M. 2012. Polyextremotolerant black fungi: oligotropism, adaptive potential, and a link to lichen symbioses. Front. Microbiol. 3: 1-6.

Goward, T. 2010. Twelve readings on the lichen thallus IX. Paralichens. Evansia, 27(2): 40-46.

Grube, M., and Berg, G. 2009. Microbial consortia of bacteria and fungi with focus on the lichen symbiosis. Fungal Biol. Rev. 23(3): 72-85.

Grube, M., Cardinale, M., Castro, J.V. Jr., Müller, H., and Berg, G. 2009. Species-specific structural and functional diversity of bacterial communities in lichen symbioses. ISME Journal, 3: 1105-1115.

Grube, M., Berg, G., Andrésson, Ó. S., Vilhelmsson, O., Dyer, P.S., and Miao, V.P.W. 2014. Lichen genomics: Prospects and progress. In The Ecological Genomics of Fungi. Edited by F. Martin, John Wiley and Sons, Inc. pp. 191-212.

Guzow-Krzeminska, B., and Stocker- Wörgötter, E. 2013. In vitro culturing and resynthesis of the mycobiont Protoparmeliopsis muralis with algal bionts. Lichenologist, 45: 65-76.

Hametner, C., and Stocker-Wörgötter, E. 2015. Type I NR-PKS gene characterization of the cultured lichen mycobiont Xanthoparmelia substrigosa (ascomycota). In Recent 
Advances in Lichenology: Modern Methods and Approaches in Biomonitoring and Bioprospection. Edited by D.K. Upreti, P.K. Divakar, V. Shukla, and R. Bajpai. Springer, Berlin, pp. 95-110.

Harutyunyan, S., Muggia, L., and Grube, M. 2008. Black fungi in lichens from seasonally arid habitats. Stud. Mycol. 61: 83-90.

Hawksworth, D. 2004. Observations on two marine and maritime "borderline" lichens: Mastodia tessellata and Collemopsidium pelvetiae. Mycological Progress, 3: 51-56.

Honegger, R. 1984. Cytological aspects of the mycobiont-phycobiont relationship in lichens. Haustorial types, phycobiont cell wall types, and the untrastructure of the cell wall surface layers in some cultured and symbiotic myco- and phycobionts. Lichenologist, 16: $111-127$.

Honegger, R. 1985. Fine structure of different types of symbiotic relationships in lichens. In Lichen physiology and cell biology. Edited by D.H. Brown, Plenum, New York. pp. 287302.

Honegger, R. 1986a. Ultrastructural studies in lichens. I. Haustorial types and their frequencies in a range of lichens with trebouxioid photobionts. New Phytologist, 103: 785-795.

Honegger, R. 1986b. Ultrastructural studies in lichens. II. Mycobiont and photobiont cell wall surface layers and adhering crystalline lichen products in four Parmeliaceae. New Phytologist, 103: 797-808.

Honegger, R. 1990. Surface interactions in lichens. In Experimental phycology. Cell walls and surfaces, reproduction, photosynthesis. Edited by W. Wiessner, D.G. Robinson, R.C. Starr, Springer, Berlin. pp. 40-54. 
Honegger, R. 1991a. Functional aspects of the lichen symbiosis. Annu. Rev. Plant Physiol. Plant Mol. Biol. 42: 553-578.

Honegger, R. 1991b. Haustoria-like structures and hydrophobic cell wall surface layers in lichens. In Electron Microscopy of Plant Pathogens. Edited by K. Mendgen and D.E. Lesemann, Springer, Berlin. pp. 277-290.

Honegger, R. 1992. Lichens: mycobiont-photobiont relationship. In Algae and Symbioses:

Plants, animals, fungi, viruses, interactions explored. Edited by W. Reisser. Biopress Ltd., Bristol. pp. 255-275.

Honegger, R. 1993. Developmental biology of lichens. New Phytologist, 125: 659-677.

Honegger, R. 1996. Mycobionts. In Lichen Biology. Edited by T. H. Nash III, Cambridge University Press, Cambridge. pp. 24-36.

Honegger, R. 2000. Simon Schwendener (1829-1919) and the dual hypothesis of lichens. The Bryologist, 103(2): 307-313.

Honegger, R. 2012. The symbiotic phenotype of lichen-forming ascomycetes and their endo- and epi-bionts. In The Mycota - A Comprehensive Treatise on Fungi as Experimental System for Basic and Applied Research. Fungal Association IX. Edited by K. Esser, Springer, Heilderberg, Germany. pp. 288-339.

Jacobs, J.B., and Ahmadjian, V. 1971. The ultrastructure of lichens. II. Cladonia cristatella: The lichen and its isolated symbionts. J. Phycol. 7: 71-82.

Jahns, H.M. 1993. Culture experiments with lichens. Plant Syst. Evol. 187: 145-174.

Joneson, S., and Lutzoni, F. 2009. Compatibility and thigmotropism in the lichen symbiosis: a reappraisal. Symbiosis, 47: 109-115. 
Joneson, S., Armaleo, D., and Lutzoni, F. 2011. Fungal and algal gene expression in early developmental stages of lichen-symbiosis. Mycologia, 103(2): 291-306.

Junttila, S., Laiho, A., Gyenesei, A., and Rudd, S. 2013. Whole transcriptome characterization of the effects of dehydration and rehydration on Cladonia rangiferina, the grey reindeer lichen. BMC Genomics, 14: 870-883.

Kirk, P.M., Cannon, P.F., Minter, D.W., Stalpers, J.A. 2008. Dictionary of the Fungi. $10^{\text {th }}$ edition. Cromwell Press, Trowbridge, CABI, UK.

Kohlmeyer, J., Hawksworth, D., and Volkmann-Kohlmeyer, B. 2004. Observations on two marine and maritime "borderline" lichens: Mastodia tessellata and Collemopsidium pelvetiae. Mycological Progress, 3: 51-56.

Kon, Y., Kashiwadani, H., Masada, M., and Tamura, G. 1993. Artificial syntheses of mycobionts of Usnea confusa ssp. kitamiensis and Usnea orientalis with their natural and nonnatural phycobiont. J. Jpn. Bot. 68: 129-137.

Kroken, S., and Taylor, J.W. 2001. A gene genealogical approach to recognize phylogenetic species boundaries in the lichenized fungus Letharia. Mycologia, 93(1): 38-53.

Leavitt, S.D., Kraichak, E., Nelsen, M.P., Altermann, S., Divakar, P.K., Alors, D., Esslinger, T.L., Crespo, A., and Lumbsch, T. 2015. Fungal specificity and selectivity for algae play a major role in determining lichen partnerships across diverse ecogeographic regions in the lichen-forming family Parmeliaceae (Ascomycota). Mol. Ecol. 24: 3779-3797.

Legaz, M.E. 1985. The regulation of urea biosynthesis. In Surface Physiology of Lichens. Edited by C. Vicente, D.H. Brown, and M.E. Legaz, Editorial de la Universidad Complutense de Madrid. pp. 57-73.

Legaz, M.E., and Vicente, C. 1982. Two forms of arginase in Evernia prunastri thallus. 
Biochem. Biophys. Res. Commun. 104: 1441-1446.

Legaz, M-E., Fontaniella, B., Millanes, A-M., and Vicente, C. 2004. Secreted arginases from phylogenetically far-related lichen species act as cross-recognition factors for two different algal cells. Eur. J. Cell Biol. 83: 435-446.

Liba, C.M., Ferrara, F.I.S., Manfio, G.P., Fantinatti-Garboggini, F., Albuquerque, R.C., Pavan, C., Ramos, C., Moreira-Filho, C.A., and Barbosa, H.R. 2006. Nitrogen-fixing chemoorganotrophic bacteria isolated from cyanobacteria-deprived lichens and their ability to solubilize phosphate and to release amino acids and phytohormones. J. Appl. Microbiol. 101(5): 1076-1086.

Lim, F.-Y., Sanchez, J.F., Wang, C., and Keller, N. 2012. Toward awakening cryptic secondary metabolite gene clusters in filamentous fungi. Methods Enzymol. 517: 303-24.

Magain, N., and Serusiaux, E. 2015. Dismantling the treasured flagship lichen Sticta fuliginosa (Peltigerales) into four species in western Europe. Mycological Progress, 14(97): 1-33.

Martin, F., Kohler, A., Murat, C., Veneault-Fourrey, C. and Hibbett, D.S. 2016. Unearthing the roots of ectomycorrhyzal symbioses. Nature Rev. Microbiol. 14: 760-773.

Marton, K., and Galun, M. 1976. In vitro dissociation and reassociation of the symbionts of the lichen Heppia echinulata. Protoplasma, 87: 135-143.

McDonald, T.R., Gaya, E., and Lutzoni, F. 2013. Twenty-five cultures of lichenizing fungi available for experimental studies on symbiotic systems. Symbiosis, 59: 165-171.

Meeßen, J., and Ott, S. 2013. Recognition mechanisms during the pre-contact state of lichens: I. Mycobiont-photobiont interactions of the mycobiont of Fulgensia bracteata. Symbiosis, 59: $121-130$. 
Meeßen, J., Eppenstein, S., and Ott, S. 2013. Recognition mechanisms during the precontact state of lichens: II. Influence of algal exudates and ribitol on the response of the mycobiont of Fulgensia bracteata. Symbiosis, 59: 131-143.

Miao, V.P.W., Manoharan, S.S., Snæbjarnarson, V., and Andrésson, Ó.S. 2012. Expression of lec-1, a mycobiont gene encoding a galectin-like protein in the lichen Peltigera membranacea. Symbiosis, 57: 23-31.

Millanes, A.M., Fontaniella, B., Garcia, M.I., Solas, M.T., Vicente, C., and Legaz, M.E. 2004. Cytochemical location of urease in the cell wall of two different lichen photobionts. Tissue and Cell, 36: 373-377.

Molina, M.C., and Vicente, C. 1995. Correlationships between enzymatic activity of lectins, putrescine content and chloroplast damage in Xanthoria parietina phycobionts. Cell Adhesion and Communication, 3: 1-12.

Molina, M. C., Muñiz, E., and Vicente, C. 1993. Enzymatic activities of algal-binding protein and its algal cell wall receptor in the lichen Xanthoria parietina. An approach to the parasitic basis of mutualism. Plant Physiol. Biochem. 31: 131-142.

Muggia, L., Gueidan, C., Knudsen, K., Perlmutter, G., and Grube, M. 2013. The lichen connections of black fungi. Mycopathologia, 175: 523-535.

Muggia, L., Perez-Ortega, S., Kopun, T., Zellnig, G., and Grube, M. 2014. Photobiont selectivity leads to ecological tolerance and evolutionary divergence in a polymorphic complex of lichenized fungi. Ann. Bot. 114: 463-475.

Muggia, L., Fleischhacker, A., Kopun, T., and Grube, M. 2016. Extremotolerant fungi from alpine rock lichens and their phylogenetic relationships. Fungal Diversity, 76: 119-142. 
Oliver, E., Crittenden, P.D., Beckett, A., and Brown, D.H. 1989. Growth of lichen-forming fungi on membrane filters. Lichenologist, 21: 387-392.

Opanowicz, M., and Grube, M. 2004. Photobiont genetic variation in Flavocetraria nivalis from Poland (Parmeliaceae, Lichenized Ascomycota). Lichenologist, 36: 125-162.

Ott, S. 1987a. Sexual reproduction and developmental adaptations in Xanthoria parietina. Nord. J. Bot. 7: 219-228.

Ott, S. 1987b. Reproductive strategies in lichens. In Progress and Problems in Lichenology in the Eighties. Edited by E. Peveling, Bibliotheca Lichenologica, 25: 81 - 93.

Ott, S., Meier, T., and Jahns, H.M. 1995. Development, regeneration, and parasitic interactions between the lichens Fulgensia bracteata and Toninia caerulonigricans. Can. J. Bot. 73: $595-602$.

Pérez-Ortega, S., de los Rios, A., Crespo, A., and Sancho, L.G. 2010. Symbiotic lifestyle and phylogenetic relationships of the bionts of Mastodia tessellata (Ascomycota, Incertae sedis). Am. J. Bot. 97: 738-752.

Piercey-Normore, M.D. 2004. Selection of algal partners by lichen fungi and patterns of variation for three species of Cladonia. Can. J. Bot. 82: 947-961.

Piercey-Normore, M.D. 2006. The lichen-forming ascomycete Evernia mesomorpha associates with multiple genotypes of Trebouxia jamesii. New Phytologist, 169: 331-344.

Piercey-Normore, M.D. 2009. Vegetatively reproducing fungi in three genera of the Parmeliaceae share divergent algal partners. Bryologist, 112(4): 773-785.

Ren, D., Liu, Y., Yang, K.Y., Han, L., Mao, G., Glazebrook, J., and Zhang, S. 2008. A fungalresponsive MAPK cascade regulates phytoalexin biosynthesis in Arabidopsis. Proc. Natl. Acad. Sci. U.S.A. 105: 5638-5643. 
Richardson, D.H.S. 1985. The surface physiology of lichens with particular reference to carbohydrate transfer between the symbionts. In Surface Physiology of Lichens, Edited by C. Vincente, D.H. Brown, and M.E. Legaz, Editorial de la Universidad Complutense de Madrid, pp. 25-55.

Richardson, D.H.S., Hill, D.J., and Smith, D.C. 1968. Lichen physiology. XI. The role of the alga in determining the pattern of carbohydrate movement between lichen symbionts. New Phytologist, 67: 469-486.

Sangvichien, E., Hawksworth, D.L., and Whalley, A.J. 2011. Ascospore discharge, germination and culture of fungal partners of tropical lichens, including the use of a novel culture technique. IMA Fungus, 2: 143-153.

Schaper, T., and Ott, S. 2003. Photobiont selectivity and interspecific interactions in lichen communities. I. Culture experiments with the mycobiont Fulgensia bracteata. Plant Biol. 5: $441-450$.

Spribille, T., Tuovinen, V., Resl, P., Vanderpoo, D., Wolinski, H., Aime, M.C., Schneider, K., Stabentheiner, E., Toome-Heller, M., Thor, G., Mayrhofer, H., Johannesson, H., McCutcheon, J.P. 2016. Basidiomycete yeasts in the cortex of ascomycete macrolichens. Science, 353(6298): 488-492. doi:10.1126/science.aaf8287.

Staley, J. T., Palmer, F. E., and Adams, J. B. 1982. Microcolonial fungi: common inhabitants on desert rocks? Science, 215: 1093-1095.

Stocker-Wörgötter, E. 1991. Thallus formation of two cyanobacterial lichens: Peltigera didactyla and Peltigera praetextata, under laboratory conditions. Bulletin de la Société Botanique de France, Lettres Botaniques, 138(3): 179-187. 
Stocker-Wörgötter, E. 1995. Experimental cultivation of lichens and lichen symbionts. Can. J. Bot. 73S: 579-589.

Stocker-Wörgötter, E. 2001. Experimental studies of the lichen symbiosis: DNA-analyses, differentiation and secondary chemistry of selected mycobionts, artificial resynthesis of two- and tripartite symbioses. Symbiosis, 30: 207-227.

Stocker-Wörgötter, E. 2002. Resynthesis of photosymbiodemes. In Protocols in lichenology: Culturing, biochemistry, ecophysiology, and use in biomonitoring. Edited by I. Kranner, R. Beckett, and A. Varma. Springer, New York. pp. 47-62.

Stocker-Wörgötter, E., and Türk, R. 1991. Artificial resynthesis of thalli of the cyanobacterial lichen Peltigera praetextata under laboratory conditions. Lichenologist 23 (2): 127-138.

Thomas, E.A. 1939. Über die Biologie von Flechtenbildnern. Beitr. Kryptogamenfl. Schweiz, 9: $1-208$.

Trembley, M.L., Ringli, C., and Honegger, R. 2002. Morphological and molecular analysis of early stages in the resynthesis of the lichen Baeomyces rufus. Mycological Research, 106: $768-776$.

Turian, G. 1977. Coniosporium aeroalgicolum sp. nov. - a dematiaceous fungus living in balanced parasitism with aerial algae. Bulletin de la Société Botanique de Suisse, 87: 1924.

U'Ren, J.M., Lutzoni, F., Miadlikowska, J., and Arnold, A.E. 2010. Community analysis reveals close affinities between endophytic and endolichenic fungi in mosses and lichens. Microbial Ecology, 60: 340-353.

Vicente, C. 1985. Surface physiology in lichens: facts and concepts. In Surface Physiology of Lichens Edited by C. Vicente, D.H. Brown, and M.E. Legaz, Editorial de la Universidad 
Complutense de Madrid, pp. 11-24.

Wang, Y., Liu, B., Zhang, X., Zhou, Q., Zhang, T., Li, H., Yu, Y., Zhang, X., Hao, X., Wang, M., Wang, L., and Wei, J. 2014. Genome characteristics reveal the impact of lichenization on lichen-forming fungus Endocarpon pusillum Hedwig (Verrucariales, Ascomycota. BMC Genomics, 15: 34.

Webber, M.M., and Webber, P.J. 1970. Ultrastructure of lichen haustoria: symbiosis in Parmelia sulcata. Can. J. Bot. 48: 1521-1524.

Weissman, L., Garty, J., and Hochman, A. 2005. Characterization of enzymatic antioxidants in the lichen Ramalina lacera and their response to rehydration. Appl. Environ. Microbiol. 71(11): 6508-6514.

Werth, S., Millanes, A.M., Wedin, M., and Scheidegger, C. 2013. Lichenicolous fungi show population subdivision by host species but do not share population history with their hosts. Fungal Biol. 117(1): 71-84.

Yahr, R., Vilgalys, R., and DePriest, P.T. 2004. Strong fungal specificity and selectivity for algal symbionts in Florida scrub Cladonia lichens. Mol. Ecol. 13: 3367-78.

Yahr, R., Vilgalys, R., and DePriest, P.T. 2006. Geographic variation in algal partners of Cladonia subtenuis (Cladoniaceae) highlights the dynamic nature of a lichen symbiosis. New Phytologist, 171: 847-60.

Yamamoto, Y., Yoshimura, I., and Yamada, Y. 1987. Cultures of Usneaceae species and growth factors in their cultured tissues. In Progress and Problems in Lichenology in the Eighties. Edited by E. Peveling, Bibliotheca Lichenologica No. 25. J. Cramer, Berlin-Stuttgart, pp. $163-165$. 
Yoshimura, I., Kurokawa, T., Nakano, T., and Yamamoto, Y. 1987. A preliminary report of cultures of Cladonia vulcani and the effects of the hydrogen ion concentration on them. Bulletin of Kochi Gakuen College, 18: 335-343.

Yoshimura, I., Kurokawa, T., Yamamoto, Y., and Kinoshita, Y. 1993. Development of lichen thalli in vitro. Bryologist, 96(3): 412-421. 